УДК 347.151+342.7+341.231

ПРАВО ЖИТИ, ПРАВО ПОМЕРТИ

\author{
Олександр Кіцера \\ Львівський національний медичний університет імені Данила Галицького, \\ Львів, Україна, ookitsera@gmail.com
}

\begin{abstract}
Автор - лікар і педагог вищої школи намагається відповісти на болюче питання: чи припустима в сучасному світі евтаназія щодо невиліковних хворих, калік, психічно неповносправних, щодо ще не народжених дітей з виявленими пренатально дефектами розвитку. Ставиться також питання - чи допустима участь лікаря в добровільному відході людини у вічність - суїциді.
\end{abstract}

Опираючись на історичні факти, твори красного письменства, публікації в пресі, висловлювання провідних авторитетів християнської церкви і на власний клінічний досвід, автор стверджує, що позбавлення людини життя несумісне з етикою медичного працівника. Завдання медпрацівника - передусім боротьба з явищами, які супроводять термінальну стадію хвороби і принижують людську гідність пацієнта.

Ключові слова: евтаназія, суїцид, закінчення життя,суїцид у супроводі лікаря, термінальна стадія хвороби.

\title{
THE RIGHT TO LIVE. THE RIGHT TO DIE
}

\author{
Aleksander Kitsera \\ Danylo Halytsky Lviv National Medical University, Lviv, Ukraine, ookitsera@ \\ gmail.com
}

The author - doctor and the high education teacher is trying to answer the painful question: Is euthanasia for incurable patients, crippled, mentally handicapped, unborn children with identified prenatal defects in development, possible in modern world. The question also concerns the doctors participation admissibility in the voluntary departure of a person into eternity - a suicide.

How can economic calculations and mental characteristics be applied to the estimation of assessing life value for persons with limited physical and/or mental capabilities, or to unborn children? What should the attitude model of a medical worker to a person be in the terminal phase of life? The author points on the medical ethic classics views and the views of philosophers, in particular, the economists-utilitarianists. He also stops on criticism of utilitarian approach to assessing the life value for the disabled person.

According to the historical facts, works of literature, press publications, leading authorities of the Christian church statements, according to his own clinical experience, the author states that the deprivation of human life is incompatible with the medical worker ethics. His task is, above all, the fighting against the phenomenas that accompany the terminal stage of the disease and humiliate the patient's human dignity.

Key words: euthanasia, suicide, end of life, physician assisted suicide, utilitarianism, terminal stage of the disease. 


\author{
To be, or not to be: \\ that is the question... \\ William Shakespeare Hamlet, \\ Act III, Scene I
}

Ні одне з питань сучасної медичної та біологічної етики не викликає такого широкого обговорення в фаховій пресі та красному письменстві, як питання добровільного відходу з життя.

Деякі автори [5,6,20,33] вважають, що і за умов сучасних медичних технологій існує межа, поза якою медицина безсила. Це менший шанс користі для хворого, ніж 1 на 100. В цих ситуаціях лікар не зобов'язаний застосовувати активне лікування навіть тоді, коли на цьому наполягає хворий чи його родина. Вже на початку становлення реаніматології ставилося питання про межу дій щодо гальмування процесу вмирання, яка «повинна визначатися сумлінням порядної людини» [33]. Візьмімо приклад. Хворий в стані агонії, спричиненої ґенералізацією злоякісного новотвору. Системи, які ще менш-більш задовільно функціонують, це система кровообігу і дихальна. Звичайно ж, ніхто в цьому випадку не докорятиме, що черговий лікар не виконав масаж серця.

У романі лауреата літературної премії Ґонкурів за 1975 р. Еміля Ажара «Життя попереду» також ставиться питання про доцільність підтримки життєдіяльності організму, а властиво «серцево-легеневого фантома» у випадку, коли життя перетворюється на суцільну муку. Стара недолуга жінка, яка пережила жах нацистської екстермінації і катівню Освєнціма, все більше втрачає пам'ять. В наш час їй би поставили діагноз хвороби Альцгаймера. Ось що каже пані Роза своєму маленькому другові Момо: «Змусять мене жити насильно, Момо. В лікарнях завжди так роблять, вони мають на це право. Я не хочу жити довше, ніж це необхідно, а такої необхідності вже немає...У мене був приятель. У нього внаслідок катастрофи не було ні рук ні ніг, і вони мучили його в лікарні ще десять років, щоб досліджувати його кровообіг. Момо, я не хочу жити виключно тому, що цього вимагає медицина. Я знаю, що втрачаю голову, і не хочу жити впродовж років без свідомості, щоби стати гордістю медицини» [1].
Лише згодом стало відомо, що Еміль Ажар це ще один псевдонім Романа Касєва, сина Ар'є Лейба Касєва (або ж, за легендою, кіноактора Івана Мозжухіна) і провінційної актриси Міни Овчинської. Перше його псевдо звучало як «Роман Ґарі».

За вмілим містифікатором Романом Касєвим, чи то в ролі письменника Романа Ґарі, чи то Еміля Ажара, чи на військовій або дипломатичній службі, ходив слідом привид суїциду, привид відходу з життя за власним бажанням. Зрештою, він таки закінчив своє життя самогубством. В автобіографічному романі «Обіцяння на світанні» він згадував про те, що один з його товаришів, Пер'є, якось застав його в квартирі «під москітною сіткою з притиснутим до скроні дулом револьвера і в нього тільки стало часу кинутися на мене, щоб відвернути постріл». Він таки закінчив життя пострілом у скроню. В передсмертній записці написав: «Можна пояснити все нервовою депресією. Але в такому випадку треба мати на увазі, що вона триває з того часу, коли я став дорослою людиною і що саме вона допомогла мені займатися літературним ремеслом»[3].

Все більше уваги в закордонних публікаціях $[5,6,11,13,17,36]$ присвячено питанню закінчення життя (англ: end of life), зокрема евтаназії, питанню асистування лікаря в самогубстві (англ: physician assisted suicide).

Рада Європи ще в червні 1999 р. висловилася за цілковиту заборону евтаназії. Адже, як справедливо зауважив журналіст Олекса Залуцький, евтаназія - явище, за своєю природою, схильне до саморозвитку. Випускаючи джина з пляшки, ми вже не зможемо контролювати його дії. Очолювана лікарем Карлом Брандтом нацистська програма мала результатом «добру смерть» у спеціальних центрах 275000 осіб, які страждали на шизофренію, паркінсонізм, пухлини мозку, згодом - дітей з вродженими вадами розвитку та розумово неповноцінних.

У відомому романі «Аеропорт» [14] канадський письменник Артур Гейлі писав: «Кожного разу, коли людство вступає в нову епоху, дещо кращу, світлішу аніж попередня, це ставалося тому, що люди більше піклувалися своїми близькими, шанували їх, як особистості. I, як лиш переставали дбати про них, людство робило крок назад... Дивно, але люди одним розчерком пера обґрун- 
товують необхідність знести кару смерті легалізувати переривання вагітності».

У Норвегії можна легально убивати дітей в лоні матері до 12 тижня вагітності. Можна вміло усунути одного з небажаних близнят [9].

В країнах ЄС триває селекція людей за іншими показниками. Евтаназія хворих на психічні хвороби та старечу деменцію стає все частішим явищем у Бельгії та Голландії. Нещодавно опублікували та розглядали в парламенті рапорт Бельгійської федеральної комісії щодо «контролю та оцінки евтаназії». Зрештою, Бельгія легалізувала асистоване самогубство ще 2002 р., а 2014 р. бельгійський парламент ухвалив закон про евтаназію для неповнолітніх без будь-яких вікових обмежень [9].

Католицька церква категорично протестує проти активної евтаназії. Натомість вона рекомендує створювати умови для паліативної допомоги, передусім - боротьби з болем, навіть ціною деякого скорочення тривалості життя.

Згадую першу зустріч медичної громади Львова з блаженнішим кардиналом, того часу - ще звичайним ієромонахом Любомиром Гузаром, яка відбулася, якщо не помиляюся, 1992 р. в аудиторії нормальної анатомії нашого університету. На запитання «Як Ви ставитеся до евтаназії?» владика відповів: «Ми мусимо дивитися на хворого не нашими, а його очима» і додав: «Одна з різниць поміж Сходом і Заходом полягає у відношенні до людини». Минуло багато років і ми виразно бачимо цю різницю у ставленні до поранених і полонених вояків в Україні і Росії, також і з боку росіян на окупованій ними території.

Серед десяти способів, якими диявол нас дурить, інтернет-тижневик «Credo» [9] наводить п'ятий із них - утилітаризм.

Мама перебуває в будинку пристарілих. У неї старечий маразм. Утримувати її там дорого. Лікарі пропонують зробити їй ін'єкцію так, «що буде по проблемі». Не роби цього. Утилітаризм - це те, через що ми вбиваємо мільйони дітей абортами...Зверніть увагу, як часто утилітаризм пов'язаний з сентименталізмом: «Ти ж не хочеш, щоб твоя мама i далі страждала?Ти ж не дозволиш так ставитися навіть до свого пса!»
Представниками класичного утилітаризму XIX століття були John Stuart Mill (1806-1873) та Jeremy Bentham 1748-1832) [32,35]. Утилітаризм - це (схильність) базувати моральні вибори та вірування лише на тому, що видається ефективним, вигідним і корисним, економічним. Корисним, з його погляду, $\epsilon$ лише те, що створює перевагу, задоволення, благо, щастя. Відповідно, якісним $є$ лише життя, яке наділене цими властивостями, натомість життя, позбавлене цих характеристик, $є$ «нелюдським», позбавленим будь-якої цінності і не гідним для продовження. Carl Menger (11840-1921) навіть побудував шкалу корисності на підставі ранжування благ за їхньою цінністю для споживача [25].Такий прагматично-утилітарний підхід до вартості життя опирається вже не на його сакральності, а на економічних розрахунках витрачених коштів і їхньої співмірності рокам якісного життя (англ: quality-adjusted life years).

Певною мірою їм заперечує християнський філософ, представник класичного неоконтрактуалізму Н. Tristam Engelhardt (нар.1941р.) у своїх капітальних працях з біоетики [10]. Хоча і у цього філософа $\epsilon$ елементи утилітаризму. За Енґельгардтом «Моральна спільнота формується з людей, наділених здатністю самовизначатися, раціонально і морально мислити».

Така концепція вилучає зі спільноти осіб, які, на певному рівні розвитку, ще не здатні самовизначатися і раціонально, морально мислити (ембріони, плоди, діти), та тих, що таку здатність втратили (особи з хворобою Альцгаймера, пацієнти в комі). Отже, ембріон у стадії, коли ще не завершене формування нервової системи, особа, для якої (в нашому, звичайно, розумінні) страждання перевищує задоволення, а також той, хто спричинює своїм близьким більше негативних емоцій, моральних страждань, аніж задоволення, підлягає знищенню? Щось тут не пов'язується з християнською мораллю. Але читаймо далі: «Початок біологічного життя людини - це не початок життя особи...» Тому «під час аборту нікого (тобто жодну особу) не вбивають, хоча й відбувається знищення людського організму».

Утилітаризм справедливо критикують сучасні філософи-економісти, зокрема - лауреат Нобелівської премії за 1998 р. Амартія Сен (Amartya Sen, 1933 р. нар.). Індійський економіст пише: «Через те, що підставою вимірювань в рамках утилітаризму $\epsilon$ ментальні 
характеристики (задоволення, щастя, або бажання), об'єктивність цих вимірювань піддається сумнівам через здатність свідомості людей пристосовуватися до постійних втрат (особливо за тяжких обставин, коли необхідно зробити життя можливим)» [29].

Вже згаданий Артур Гейлі пише: «Що ж стосується економічних міркувань, то ними можна обґрунтувати що завгодно. 3 економічного погляду логічно вбивати одразу по народженні розумово скривджених, дебілів, застосовувати евтаназію щодо невиліковних хворих, позбуватися старих і людей, що не приносять суспільству користі, так, як це роблять в Африці, залишаючи їх в джунглях на пожертя гієнам».

Сучасна біоетика має своїм фундаментом, зокрема, моделі лікарської етики Гіпократа, Маймоніда та Парацельса.

Визначний арабський і юдейський лікар Маймонід у своїй «Молитві Маймоніда» промовляв:

«Нехай при спілкуванні з хворим мій розум залишається ясним, не обтяженим жодною сторонньою думкою, щоби я виразно усвідомлював те, чому мене навчили досвід і наука, бо ж величними і розкішними $є$ пошуки, що мають за мету підтримання життя і здоров'я всіх сотворінь»(підкреслення автора) [18]. Гіпократ у своїй «Клятві» присягав: «Вживатиму ліки на користь хворому відповідно до моїх знань і переконань, але утримаюся від їх застосування на шкоду і кривду. Нікому не дам отрути, хоч би він просив мене про це, ані не буду її радити нікому. Так само не дам жінці засобу для видалення плоду» (підкреслення автора) [18].

Та й у патерналістичній моделі етики Парацельса акцентується увага на використанні контактів лікаря з пацієнтом задля доброчинності, милосердя, полегшення його страждань» [4].

Польські та англійські автори $[8,13,14$, $17,36]$ наголошують, що право невинної особи на життя ніхто не може піддавати сумніву. Зрештою, згода пацієнта на евтаназію може бути вимушеною, наприклад, спадкоємцями. Інколи прохання про смерть насправді драматизоване прохання про допомогу, ще одна спроба промовити до сумління близьких, розбудити в них почуття вини, милосердя.
Не вважають евтаназією припинення застосування в термінальному стані реанімаційних заходів, відмова від інтенсивної терапії та надзвичайних засобів, штучного годування $[3,6,13]$.

Лікар зобов'язаний зберігати, щадити і продовжувати людське життя так довго, як це можливо доти, доки це має сенс.

Біоетика не перестає ставити до нас вимоги і тоді, коли хворий перебуває в аґональному стані. В романі англійської письменниці Сюзен Гілл «Нічний птах» [16] молодий вразливий поет розповідає про смерть сусіда по ліжку в лікарні: «Вони оточили його ширмою, а я лежав і чув, як він умирає. Прийшов лікар і крикнув йому до вуха "Чи ви чуєте мене, пане Бедовс? Чи ви мене чуєте?" Потім почали розмовляти про нього над його головою: - Це ще трохи потриває. Ці старі завжди повільно відходять. Звідкіля вони знали, що він їх не чує. Як вони посміли говорити про нього так, як коли 6 він був твариною, як коли 6 він уже не жив. Я думав, що уб'ю їх».

Кожної святої Літургії християни просять Всевишнього «християнської кончини життя нашого, безболісної, непостидної, мирної...» Непостидної... Мимоволі згадується типова, на жаль, ситуація: лежить на ліжку оголений вмираючий. I всі вважають, що так воно і повинно бути, і нікому прикрити наготу його, бо кудись поділися Сим і Яфет. А залишився лише той третій син Ноя... А може у нещасного збереглися залишки свідомості?

Стефан Цвайґ вважав страхітливим афоризм Ніцше: «Не беріться лікувати невиліковне!» «Назвавши хворого невиліковним, лікар ухиляється від виконання свого обов'язку, він капітулює перед битвою». 3 письменником неможливо погодитися на сто відсотків. Сучасні медичні технології дають змогу виконувати надскладні втручання, які Ван-дер-Веер [36] називав «гротескними гемікорпоректоміями». Після таких операцій життя пацієнта перетворюється на суцільну муку й упокорення.

3 погляду біоетики в сучасній онкології проводиться межа між етичним і неетичним радикалізмом. Якщо існують шанси порятунку життя пацієнта за умови збереження або деякого погіршення якості життя, то хворому можна пропонувати таке втручання, залишаючи йому право остаточного рішення $[13,17]$. Якщо пе- 
редбачається, що після операції життя пацієнта ймовірно перетвориться на суцільну муку і стане ненависним йому, то пропонувати таке втручання неетично. Цілком неприпустимо розширювати покази до таких хірургічних втручань 3 комерційних чи престижних міркувань.

У типовій 50-ліжковій палаті лондонського шпиталю вмирав від раку емігрант з Польщі, втікач з Варшавського ґетто Давид Тасьма. В останні дні життя він довго розмовляв з медичною сестрою Сесіль Сандерс про необхідність вдосконалювати мистецтво зменшувати страждання. Перед смертю він вручив сестрі Сесіль усі свої заощадження - 500 фунтів стерлінгів. Ці гроші він заповів вимріяному шпиталеві для безнадійно хворих, вмираючих людей. Сестра Сандерс здобула вищу медичну освіту i, зібравши за підпискою фонду, у 1967 р. відкрила шпиталь святого Христофора, в якому і нині шукають можливості зменшувати фізичні та психічні страждання безнадійно хворих [7].

Мати Тереза з Калькутти, в миру албанка Ґанджу Боянджу, 1979 р. отримала Нобелівську премію миру за допомогу знедоленим і вмираючим, щоб, як вона писала: «в останні години, що їм залишилися, не дати їм відчути самотності» [27].

Студентам і слухачам факультету післядипломної освіти я, звичайно, розповідаю такий випадок з практики [21]: «В ізоляторі нашої клініки лежав смертельно хворий лікар, мій шкільний товариш. Він вже впродовж тижня нічого не їв, трубка для дихання була проведена крізь ракову пухлину трахеї в лівий бронх. Наркотики, навіть у збільшених дозах, лише частково гамували біль. Біля ліжка хворого зібралися лікарі-однокурсники, друзі. Коли вийшли в коридор, хтось із лікарів сказав: "Не можу дивитися на його муки. Чи не гуманніше було 6 увести йому достатню для... повного припинення страждань дозу наркотика?"-"А хто введе?"- запитав інший. -Ти? А може Ти?.. Всі відмовилися. Виникла ситуація, схожа на описану Е. Гемінґвеєм в оповіданні "Натуральна історія померлих" [15]. Але справа не лише в цьому. Наступного ранку мій пацієнт покликав мене жестом і тремтячою рукою написав на клаптику паперу: «Розкажи мені, що було вчора на з'їзді письменників...»

Ось вам і відповідь на суперечку про евтаназію. Вбиваючи тіло, ніколи не можна бути впевненим, що не вбито інтелект. Тут доречно згадати висловлювання Аристотеля, яке навів владика Любомир Гузар під час уже згаданої першої зустрічі з медиками Львова. «Homo est animal sociale» (Людина - соціальна істота). Український філософ Памфил Юркевич (1827-1874) вчив, що людська природа $є$ кінцевим проявом нескінченного [4]. Вона одна у відомому нам світі...має власне, особистісне існування в часі і просторі» [19].

Зате зменшення страждань тяжко хворої людини, боротьба з болем до останньої можливості, милосердя - це моральний обов'язок кожного лікаря.

\section{REFERENCES}

1. Azhar Emil Vsia zhyzn' vperedi (All life is ahead): Translation from French V.Orlova.-Ozon.ru.2010:240. [In Russian]

2. Anisimov M. Romen Gary, khameleon (Romain Gary, chameleon) Translation from French EV. Havrilova). N.Novhorod:DEKOM. 2007:640. [In Russian]

3. Angelos P. Ethical guidelines in surgical patient care. Journal of the American College of Surgeons. 1999 Jan $31 ; 188(1): 55-8$.

4. Berko P, Derzhko I, Pitula H, Nebeluk M. Filosofs'ki problemy medycyny (Philosophical problems of medicine) Lviv,Boryslav. 2011:377-385.

5. Białowąs M. Z rozmyślań o śmierci (Reflections about death) Wiad.Lekarskie. [In Polish]. $1981 ; 34(18): 1581-1583$

6. Blicharski J. Postępowanie z nieuleczalnie chorym (Conduct with an incurable patient).PZWL Warszawa. 1959:211.

7. De Boulay S, Rankin M. Okno nadzieji - założycielka ruchu hospicyjnego (Cicely Saunders. The Founder the Modern hospice). Translation from English. Warszawa «Znak». 2016:400. [In Polish]

8. Dahlgren G., Whitehead M. Politika i srategija obiespietshenija spraviedlivosti v voprosah ohrany zdorovja (A policy and strategy of providing of justice in the questions of the health care). BO3 Kopenhagen. [In Russian] 1992:56.

9. Desiat' sposobiv, yakymy dyjavol nas duryt' (Ten ways in which the devil is fooling us) - Credo/chasopys. www.credo-ua.org/2016/12/170793/. [In Ukrainian] 
10. Engelhardt HT. Bioethics and secular humanism: The search for a common morality. Wipf and Stock Publishers; 2011 Apr 1:224.

11. Frysh Maks Pomoch umeret'? (Help to die?). Njedjela. . 1988;(38):11. [In Russian]

12. Gary Romain Obitsiannia na svitanku (Promise at dawn): Translation from French Maryna Marchenko. K.I.S Kyiv. 2011:374.

13. Głuszek St. Wybrane problemy etyczno-moralne chirurgii (Elected ethic problems of surgery) $\mathrm{O}$ chirurgii polskiej końca XX wieku.-Fund. Polski Przegląd Chirurgiczny Warszawa. 2001:5-17. [In Polish]

14. Hailey A. Port lotniczy (Airport). Translation from English. «Iskry» Warszawa. 1987:269-270. [In Polish]

15. Hemingway E. A natural history of the dead, Hemingway- A-Natural-History-of-the-Dead. www.24 grammata.com_.pdf [In English]

16. Hill Susan - Ptak nocy (The Bird of Night) Translation from English. Czytelnik Warszawa. 1978:270. [In Polish]

17. Janczewski G. Wybrane zagadnienia medyczno-prawne w relacjach otolaryngolog-pacjent (Elected ethic and legally problems in relation otolaryngologist-patient). Problemy laryngologiczne w codziennej praktyce. Servier Polska Warszawa. 2000;(22):2-9. [In Polish]

18. Janczewski G. List do Redakcji (A letter to the Publisher) Otolaryngologia Polska 2004;58(3):1-2. [In Polish]

19. Jurkevich P. Vybrane (Elected works). Kyjiv Abriss. 2011:397. [In Ukrainian]

20. B.Nadraha. Khartija pratsivnykiv okhorony zdorovja (Charter of health workers) Translation from Polish. Papska Rada do sprav dushpastyrstva v okhoroni zdorovia. 1995: Lviv 1999:128. [In Ukrainian]

21. Kitsera O. Mystetstvo buty likarem (Art to be a doctor). Medychni Kadry veresen, zhovten. 1984;(27)11. (29):2-2. (30):2-2. (31):2-2. [In Ukrainian]

22. Kitsera O, Kitsera $\mathrm{O}(\mathrm{jn}$.). Likar, jak faktor ryzyku (The doctor as a risk factor).Informovana zhoda conditio sine qua non (Informed consent- conditio sine qua non) Likar i pjata zapovidj (Doctor and the fifth command).-Deontolohichni aspekty rozmovy likarja $z$ hvorym (Deontological aspects of a physician's conversation with a patient). Formuvannia osobystosti studentiv, yak maibutnikh fahivtsiv likarskoi spravy, pratsivnykiv okhorony zdorovia ta inshyh sotsialno-orientovanykh ustanov u konteksti bioetyky (tezy dopovidej) Lviv. 2003;86-88. [In Ukrainian]

23. Kundiev Yu. Bioetyka-velinnia chasu (Bioethics is the command of the time). Liky Ukrainy. 2002(11):5557. [In Ukrainian]

24. Krokos J. Mówić prawdę choremu (To tell a patient the truth). Polski przegląd Chirurgiczny. 1992;(64): 677-680. [In Polish]

25. Leube K.R. von Das Ich und der Wert docs.mises.de/Leube/Leube_Menger.pdf

26. Lidz M., Meisel L. Informed consent and the structure of medical care. President's Comission for the Study of Ethical Problems in Medicine.Making Health Decisions. 1998:17-374.

27. Lush Gjergji Matka miłośći (Mother of love). Translated Andrzej Spurgjasz. VELAR ed. Litonova. 1994:220.

28. Mill J.S. The Principle of Beneficence in Applied Ethics. Stanford Encyclopedia of philosophy https:// plato.stanford.edu/entries/mill/

29. Morew D. A. Amartya Sen i ogranichennostj utalitarisma (Amartia Sen and the limit nature of utilitarianism). Ekonomicheskije nauki. . 2010;8(69):37- 41. [In Russian]

30. Nadraha B. Khrystyjansjka etyka, jak osnova medychnoji deontolohii (Christian ethics as the basis of medical deontology). Narodne Zdorovja. 1993 kvitenj;9-10(37-38):1-2. [In Ukrainian]

31. Pyrih L. Likarju, bud' inteligentom! (Doctor, be an intellectual!). Medychni Kadry. 1988 hrudenj;(35):2-2. [In Ukrainian]

32. Sgreccia E, Spagnolo A, Di Pietro ML. (red.) Bioetyka (Bioethics).Medycyna i pravo. Lviv. 2007:425451,563-580. [In Ukrainian]

33. Sykh M. (red.) Resustsytatsia. Teoria i praktika ozhyvlenia (Theory and practice of resustitation). Translation from Polish. Pol.med.izdatelstvo. Warshava. 1976:332. [In Polish]

34. Tatarkiewicz W. Historia filozofii (History of philosophy). T1. Filozofia starożytna i średniowieczna (Ancient and medieval philosophy):81-90. T.2 Filozofia nowoożytna do roku 1830 (History of more new times till 1830):152-157, T.3 Filozofia XIX wieku i współczesna (XIX century and modern philosophy):38-41. PWN.-Warszawa, 1999. (In Polish)

35. The History of Utilitarianism//Stanford Encyclopedia of Philosophy https://plato.stanford.edu/entries/ utilitarianism-history/

36. Van der Veer J.B. Euthanasia in the Netherlands. Journ. of American Coll.Surg. 1999;(188):532-537. [In English] 